Rok XIV (2019) | 2 (28) | s. 233-244

https://doi.org/10.12797/LV.14.2019.28.15

Anna Kałkowska ๑

Instytut Języka Polskiego Polskiej Akademii Nauk, Kraków

az_kalkowscy@op.pl

\title{
ZENON KLEMENSIEWICZ W SWOIM CZASIE. ZE WSPOMNIEŃ UCZENNICY
}

Słowa klucze: Zenon Klemensiewicz, dydaktyk, osobowość, uczony, biografia, rola społeczna Keywords: Zenon Klemensiewicz, teacher, personality, scholar, biography, social role

Kraków połowy zeszłego wieku był miastem depresyjnym, zwłaszcza dla ludzi przybyłych z zewnątrz. Mgły ciągnące od Wisły, dziwny duszny wiatr, słabo oświetlone ulice, mroczne kościoły; społeczność krakowska za zamkniętą na głucho już od 10 wieczorem bramą, uchylaną za „szperą” przez gderliwe „dozorcowe” lub ponurego ciecia.

Do tego siermiężna codzienność głębokiego PRL-u, życie studenta głodne, szare, bez rozrywek i okazji towarzyskich, i jeszcze ciągle niebezpieczne. Walka klas to nie był slogan z podręczników marksizmu. Rozgrywała się także w tych salach. Ojciec za granicą przynosił wstyd, był przyczyną szykan, należało się go expressis verbis wyprzeć i potępić przed gromadą rówieśników. Tak łamano młode sumienia.

Donosy były na porządku dziennym - młodzi rewolucjoniści urządzali sądy nad swoimi profesorami, światowej sławy autorytetami, za nieostrożną ironiczną czy mało entuzjastyczną wypowiedź o socjalistycznej rzeczywistości. Pozbawiano ich prawa do nauczania, kontaktu z młodzieżą w sposób upokarzający, bez zważania na wiek czy zasługi. Znamy ich nazwiska: Juliusz Kleiner, Jerzy Kuryłowicz, Roman Ingarden... 
Odbierałam tę nową dla mnie rzeczywistość szczególnie dotkliwie - przyjechałam na studia $z$ Lublina, miasta po wojnie właściwie kresowego, otwartego na fale repatriantów ze Wschodu, ale także ocalałych z łagrów sowieckich. Również przez mój dom przepływała rodzina z Łucka, Wilna, Lwowa, Grodna, Pińska, z opowieściami o wstrząsających doświadczeniach - także rzezi wołyńskiej.

Ucieczkę przed tymi przerastającymi odporność nastolatki emocjami znajdowałam w szkole - były to ostatnie lata funkcjonowania Liceum ss. Urszulanek, gdzie w zadbanych, wyciszonych wnętrzach, izolowanych od powszechnej indoktrynacji, udało mi się dotrwać do matury. Mimo wyniesionej stamtąd niepoprawności politycznej (nie należałam do żadnej organizacji młodzieżowej) poziom nauczania, z którego te szkoły słynęły, pozwolił mi się dostać na polonistykę na Uniwersytet Jagielloński.

Na tym tle Kraków, w zasadzie oszczędzony przez wojnę, wydawał się innym, zamkniętym światem. Także wśród młodych, na uczelni odczuwało się wyraźny podział na elitarną mieszczańsko-arystokratyczna grupę miejscowych i przyjezdnych, gnieżdżących się w akademikach i na legendarnych krakowskich stancjach. Z czasem jednak zaprzyjaźnialiśmy się, łączeni krystalizującymi się zainteresowaniami, uczyliśmy się razem do egzaminów - i zostały dobre wspomnienia. Różnice poglądów i pochodzenia nie okazały się decydujące.

Ale ulubionym azylem stały się dla mnie dwie instytucje. Szybko odkryłam Jagiellonkę, której elegancki przedwojenny wystrój przenosił nas w inny wymiar, tak różny od codziennych, dość prymitywnych warunków bytowania. Czytelnia główna $\mathrm{z}$ wygodnym stołem i kręgiem lampy dla każdego była idealnym miejscem wielogodzinnych lektur. Przestronne hole z kącikami do pogadania, nieoceniony bufet! Możliwość korzystania $\mathrm{z}$ tego gmachu, zaprojektowanego $\mathrm{z}$ wyobraźnią i troską o użytkowników, jakoś nas nobilitowała, włączała w obieg wysokiej wiedzy.

Osobnym światem była ul. Gołębia 20 (pozostałe budynki nie były jeszcze dostępne). Tu znowu nie komfort i estetyka były ważne, ale postacie, które spotykaliśmy. Profesorowie Kazimierz Nitsch, Stanisław Pigoń, Witold Taszycki, Tadeusz Milewski, Kazimierz Wyka, J. Kuryłowicz, J. Kleiner, Tadeusz Lehr-Spławiński, Franciszek Sławski, Jan Safarewicz - do nich ściągaliśmy z całej Polski.

Były to indywidualności niepowtarzalne w sposobie przekazywania wiedzy, ale także w stylu bycia, temperamentach, przyzwyczajeniach, o których krążyły legendy, tworzyły atmosferę tego miejsca.

Zenon Klemensiewicz był w tym gronie jedną z najjaśniejszych gwiazd, $\mathrm{z}$ różnych, także pozanaukowych powodów. Natura wyposażyła go w cechy idola.

Jak wspominała przed 1o laty na sesji w Polskiej Akademii Umiejętności prof. Krystyna Pisarkowa, jego studentka i najbliższa współpracownica -

niezapomniany profesor Zenon Klemensiewicz cieszył się ogromnym uznaniem, szacunkiem i popularnością [...] wśród nas, studentów, podziwiających, kochających i szanujących Profesora po prostu jak ojca [...]. Mawiało się o nim „Klemens Wspa- 
niały" ze względu na same walory całokształtu jego stylu, czyli języka i wyglądu, także sposobu bycia i, oczywiście, rzeczowej zawartości wykładów. Wszyscy byliśmy świadomi, że to człowiek niezwykły: wybitny, szlachetny, uczony, „prawdziwy przedwojenny" i jednocześnie zamiłowany dydaktyk i popularyzator najlepszej polszczyzny (Pisarkowa 2011: 134).

Moje wspomnienia z okresu studiów są o parę lat późniejsze i nie tak bogate. Profesor nie prowadził już seminariów, jedynie wykład z gramatyki opisowej dla I roku. Jak wiele straciłam, mogę się domyślić z opisu tych zajęć kolejnej ówczesnej uczennicy (potem asystentki), prof. Antoniny Łęgowskiej-Grybosiowej:

Mistrzostwo dydaktyka poznawaliśmy przez dwa lata na ćwiczeniach [...]. Tu imponował wieloma cnotami społecznymi. Dalej nie było mowy o spóźnieniu, nikt by się nie ośmielił zakłócać rozpoczętej pracy. Podzieleni na zespoły, pracowaliśmy w napięciu do ostatniej minuty. Profesor nie opuszczał zajęć, nie skracał, nie pozwalał na bierność. Uczył szacunku dla osób wyraźnie nienadążających, nie kpił z nich. Cały czas uczył bez słów dystansu, rozumianego jako nieodzowna część rytuału, rytuału uniwersyteckiego. Bo to był rytuał. Rytuał, jako wzorzec zachowania przenikał później i środowisko studenckie [...] i grupę pracowników uczelni. Bardzo szybko przejmowali od Profesora model jego zachowania, model kultury wysokiej (Grybosiowa 2011: 140).

Ja poznałam jednocześnie dwa pokolenia Klemensiewiczów. Dr Irena Klemensiewiczówna (późniejsza prof. Bajerowa) wykładała na I roku gramatykę języka staro-cerkiewno-słowiańskiego, jeden z nudniejszych przedmiotów. Dzięki odziedziczonemu talentowi dydaktycznemu i własnemu temperamentowi potrafiła uczynić go interesującym.

Młodziutka, o ojcowskiej, nieco orientalnej urodzie, w bluzie jakby paramilitarnej i sznurowanych butach (wizerunek zgodny z tym, co wiedzieliśmy tajnie o jej przeszłości AK-owskiej, o narzeczonym z ciężkim wyrokiem za podziemną działalność) wkraczała do sali energicznym krokiem i nie dawała okazji do nudy, prowokowała do myślenia nawet wtedy, gdy wprowadzała nas nieustępliwie we fleksję scs-u.

Jednak do tego wojskowego stylu dołączona bywała kobieca miękkość dla podopiecznych; potrafiła ich bronić przed własnym ojcem i szefem.

Oto jedno z moich już bardzo osobistych wspomnień - ta niezwykła para chodząca dużymi krokami po korytarzu III piętra, w zwarciu ze sobą.

Głos Ireny przejęty, ale zdecydowany:

- Ojcze, ty nie możesz sprawiać, że oni zapominają języka w ustach ze strachu...

Trochę wyrozumiałości.

Profesor, wzburzony, purpurowy pod srebrnymi włosami:

- Irusiu, jakże mam im pobłażać, skoro się nie uczą, nie myślą. 
Dalszego ciągu nie wypadało mi słuchać, ale po latach już współpracownikom przyznał, że zdarzało mu się okazywać „gniew pedagogiczny” nie zawsze autentyczny, wzbudzany dla określonego celu dydaktycznego.

Do mojego życia wkroczył prof. Klemensiewicz na wykładzie z gramatyki opisowej współczesnej polszczyzny. Mieliśmy już do czynienia z różnymi wykładowcami - także literatami, zawsze wielkiej wiedzy, ale o różnym darze retorycznym. Tutaj po paru godzinach wiedzieliśmy, że mamy przed sobą mistrza. Idealnie skomponowana, zamknięta całość tematyczna, piękny, bogaty język, precyzja objaśnień, starannie dobrane przykłady. Nawet my, ledwo zaczynający studia, potrafiliśmy te rzadkie, zwłaszcza u językoznawcy, walory docenić.

Odbieraliśmy te spotkania - wraz z piękną sylwetką prowadzącego - niemal jak dzieło sztuki. Kiedyś, po szczególnie porywającym wykładzie o składnikach dodatkowych w zdaniu pojedynczym, spontanicznie zerwaliśmy się do oklasków. Profesor, już wychodząc, zatrzymał się zaskoczony - chyba niemile. To nie było w jego guście. Ktoś z nas zdobył się na przeproszenie za tę formę podziękowania za doznane przeżycie. To już go udobruchało, może nawet wzruszyło.

Program dla I roku obejmował całość gramatyki opisowej - Profesor wprowadzał nas w głosownię, fleksję, słowotwórstwo bardzo skrupulatnie, ale oczywiste się stało, że jego pasją jest składnia - i potrafił wielu z nas jej problemami głęboko zainteresować. Była to już praca nad tekstem, prowadząca z czasem do „składniowej interpretacji stylu".

Ja sama, wybierając studia polonistyczne, byłam zdecydowana na specjalizację literacką. Jednak, słuchając tych wykładów, uczestnicząc w ćwiczeniach prowadzonych bardzo interesująco przez dr Marię Brodowską (później prof. Honowską), przygotowując się do egzaminu z Zarysu składni polskiej (Klemensiewicz 1953), wybrałam inaczej. Syntaktyczne analizy tekstu w ujęciu Klemensiewiczowskim wydały się mi pasjonujące, a znaczeniowe klasyfikacje dopełnień, okoliczników, przydawek porównywalne z subtelnościami języka poezji.

Tak więc na IV (wtedy ostatnim) roku uczestniczyłam już w magisterskim seminarium Klemensiewicza. Przyznam, że temat pracy, który wybrał dla mnie Profesor, nie odpowiadał moim ambicjom i zainteresowaniom. Ja chciałam zagłębiać się w Norwida, mój promotor uznał, że większy będzie pożytek, jeśli zajmę się Nieznanymi związkami czasownika $z$ dopetnieniem w Słowniku Knapskiego. Nie miałam do tego serca, pisałam bez zapału, ale on, wytrawny dydaktyk, wiedział, że będzie to dobra wprawka do pracy nad składnią historyczną, przy której mnie widział.

I tak się stało. Po magisterium zaproponował mi pozostanie w kręgu Pracowni Składni Historycznej przy Zakładzie Językoznawstwa PAN (potem w Instytucie Języka Polskiego PAN); zostałam dokooptowana do zespołu złożonego z dwu uczennic profesora, wtedy magistrów: Krystyny Harrer-Pisarkowej i Jadwigi Koniecznej (później Koniecznej-Twardzikowej). 
Po niedobrze wspominanych studiach (była to końcówka lat stalinowskich) znalazłam w tym malutkim gronie poszerzonym o przyjazne środowisko Pracowni Słownika Staropolskiego (z którego lokalu korzystałyśmy) bezpieczny azyl, wspaniałą aurę dla ducha i umysłu. Charyzma szefa, intelektualne zalety, wyszukane poczucie humoru koleżanek, ich przyjaźń były dla mnie wtedy i na zawsze pozostaną nieocenionymi darami losu.

Okoliczności powołania oraz najwcześniejszy, trzyletni dorobek Pracowni funkcjonującej następnie przez 16 lat (od 1953 do śmierci założyciela w 1969 r.) zostały przedstawione i udokumentowane przez Klemensiewicza ze zwykłą u niego skrupulatnością w Założeniach i wytycznych działalności Pracowni Polskiej Składni Historycznej (Klemensiewicz 1958), sprawozdaniu przedłożonym na posiedzeniu Komisji Językoznawstwa PAN 20 stycznia 1956 r. Mówił wtedy:

Ale właśnie przygotowując ten zarys polskiej składni historycznej [w Gramatyce historycznej jezzyka polskiego (Klemensiewicz, Lehr-Spławiński, Urbańczyk 1955) - A.K.], przekonałem się o konieczności zorganizowania jakiegoś ośrodka badań w tym zakresie. I z tego stanowiska wystąpiłem 2 czerwca 1952 r. przed tymczasową Komisją Językoznawstwa PAN z wnioskiem o powołanie do życia małej pracowni polskiej składni historycznej przy Seminarium Języka Polskiego UJ. Wniosek uzyskał życzliwe poparcie w postaci funduszu na prace zlecone w wysokości $8000 \mathrm{zł}$ w r. 1953 , 15200 w r. 1954 [...]. Pierwsza rata została wypłacona w drugim kwartale r. 1953; organizacja personalna zajęła kwiecień, właściwa praca zaczęła się tedy w maju r. 1953 i trwa przeszło półtrzecia roku (Klemensiewicz 1958: 5).

Dalej prognozował zadania pracowni: 1) szczegółową problematyzację i klasyfikację zjawisk składniowych; 2) gromadzenie materiałów dokumentujących i ilustrujących istnienie struktur syntaktycznych obcych polszczyźnie współczesnej; 3) budowę syntetycznego ujęcia rozwoju polskiej składni. Przewidywał też rozszerzenie badań na płaszczyźnie historyczno-porównawczej na materiale słowiańskim.

$\mathrm{Na}$ wstępnym etapie pracy (wypełnianie wcześniej przygotowanego kwestionariusza materiałem źródłowym) wykonywałyśmy zadania, jak to Profesor nazywał, „zbieraczy” (dziś jest to kategoria dokumentalistów). Określenie tej funkcji w hierarchii naukowej wydaje się skromne, ale szef oddał mu sprawiedliwość, wskazując na swoistość pracy składniowca: „Już tu rad bym z naciskiem uwydatnić trudne i odpowiedzialne stanowisko zbieraczy, postawionych wobec zadania bardziej powikłanego, niż przy poszukiwaniach w wielu innych działach gramatyki” (ibid.: 7).

Dalej precyzował, jakie ważne cechy powinny go charakteryzować - przede wszystkim „rozmiłowanie w przedmiocie” $\mathrm{i}$

skrupulatne sumienie syntaktyczne, które każe zbieraczowi przedstawić swoje wątpliwości na zebraniach kontrolnych. Wtedy to wspólnie rozważamy zagadnienie i rozstrzygamy je; nie mogę zataić, że nie zawsze te rozstrzygnięcia nas zadowalają, widać nie dojrzeliśmy jeszcze do rozwikłania niektórych trudności [...] (ibid.). 
Te cotygodniowe robocze spotkania były podstawową formą naszego kontaktu z Profesorem, który przywiązywał dużą wagę do ich naukowej, ale także kontrolnej funkcji. Udało się przechować zeszyt protokołów z tych zebrań z lat 1961-1969, zapisywanych naprzemiennie przez ich uczestniczki: K. Pisarkową, J. Konieczną-Twardzikową i A. Kałkowską.

Każde spotkanie składało się z części sprawozdawczej, podsumowującej nasz „urobek” materiałowy, i analitycznej, kiedy rozważaliśmy wspólnie wątpliwości interpretacyjne jego dotyczące.

Dość, wydawało się, odległy od naszych codziennych spraw, dbał Profesor (odkryłam tego dowody w swoich dokumentach) o przeszeregowania finansowe i awanse, motywował je obficie w pismach do władz Akademii. Pewnie nie lubił tej strony swojej kierowniczej funkcji, ale nie uchylał się od niej.

Opinie na temat naszej pracy wyrażał powściągliwie - zarówno gdy był z nas zadowolony, jak i wtedy, gdy miał jakieś zastrzeżenia. Z tym większym wzruszeniem przeczytałam w odszukanym na użytek tych wspomnień „zaświadczeniu”:

poznałem p. Miłkowską [moje nazwisko rodowe - A.K.] jako utalentowaną, pilną, sumienną i gorliwą adeptkę pracy w dziedzinie językoznawstwa polonistycznego; [...] jakiekolwiek by się otworzyły przed nią możliwości zawodowej pracy z nachyleniem językoznawczym, sądzę, że wykona ją z pożytkiem i dlatego mocno popieram.

Było to tuż przed moim egzaminem magisterskim; myślałam wtedy o powrocie z przyczyn rodzinnych do Lublina i staraniu się o pracę na tamtejszej uczelni. Udało mi się jednak zostać przy Profesorze.

W roku 1957 nasze drogi organizacyjne się rozeszły: z Pracowni Składni wydzieliła się Pracownia Historii Języka (w składzie: A. Kałkowska i Krystyna Oszywianka), przewidziana jako pomoc przy powstającym właśnie dziele Klemensiewicza. Po śmierci Profesora oba zespoły (Oszywiankę niebawem zastąpiła Magdalena Nowotna-Szybistowa) połączyły się i pod szefostwem K. Pisarkowej ukończyły ekscerpcję materiału i przygotowały do druku sześć książek o zapomnianych konstrukcjach składni staropolskiej (Klemensiewicz, Pisarkowa, Konieczna-Twardzikowa 1966), średniopolskiej (Kałkowska, Pisarkowa, Twardzikowa 1972; Kałkowska 1973) i nowopolskiej (Kałkowska 1974, 1975, 1977).

2 kwietnia 1969 r. po południu - dziwne, że tak wielu z nas to pamięta - nad Krakowem przeszła burza śnieżna. Ja wracałam szybko ze spaceru z córką, K. Pisarkowa czekała na przylot męża. Jak wspomina: „[...] wrócił tym późniejszym [samolotem]. Wiadomość o katastrofie usłyszeliśmy już we dwoje" (Pisarkowa 199o: 29). Zaczęły dochodzić sprzeczne, przerażające wiadomości.

Było to także dla nas bolesne zamknięcie fragmentu życia. Zostałyśmy bez mistrza i przewodnika nie tylko po składni i historii języka.

Trzeba sobie bowiem przypomnieć znaczenie postaci Z. Klemensiewicza dla każdego, kto go - z różnych perspektyw i odległości - poznał, i dla okresu, który 
współtworzył. Wykraczało ono daleko poza językoznawstwo, było odrębną wartością życia kulturalnego, obyczajowego, narodowego. Klemensiewicz symbolizował wzorzec Polaka patrioty i naukowca, dostrzegaliśmy w nim najlepsze cechy inteligenta, spadkobiercy tradycji humanistycznych, romantyka i pozytywisty zarazem. Jak pisała I. Bajerowa:

[Był] romantykiem jednak przede wszystkim. Wbrew pozorom kierowania się tylko chłodem intelektu był to człowiek ogromnie, romantycznie uczuciowy. I z tą uczuciowością można wiązać Jego religijność, która odgrywała niemałą rolę w osobowości. Ten romantyzm był Jego wewnętrzną siłą; sam zresztą zdawał sobie z tego sprawę, czasem się do tej uczuciowości przyznawał i właściwie nie próbował przeciwdziałać, tylko ukrywał ją o tyle, o ile maksymalne opanowanie i maskowanie gwałtownych porywów serca jest przykazaniem postępowania pedagogicznego (Bajerowa 1990: $19-20)$.

Nawet dla tych, którzy Profesora z dość bliska przez dłuższy okres mieli możność obserwować, jest to spostrzeżenie odkrywcze. Był bowiem osobowością niezwykle złożoną i bogatą. We wspomnieniach współczesnych powracają takie typowo polskie cechy, jak: odwaga, niefrasobliwość, potrzeba ryzyka, towarzyskość, gościnność, dowcip i instynkt walki; imponował przy tym Profesor żelazną dyscypliną, punktualnością i słownością.

Uczonemu przypisuje się: liberalizm intelektualny, cierpliwość, skromność, szacunek i obiektywizm wobec cudzej pracy, pasję i pracowitość, poszukiwanie nowych dróg i wyzwań. Człowieka określają przymiotniki: romantyczny, męski, dowcipny, ascetyczny, samotny, tragiczny, wesoły, zasadniczy, bezpośredni, bardzo surowy i bardzo łagodny; i rzeczowniki: uczuciowość, wrażliwość, umiłowanie sztuki (był melomanem, znawcą poezji), wytworność, wewnętrzny niepokój oraz melancholia.

Powraca też we wspomnieniach dar, z którego korzystały różne kręgi słuchaczy, a także - za pośrednictwem telewizji - całe społeczeństwo. Było to krasomówstwo, umiejętność mówienia sugestywnego, pięknego, jasnego. Jego wykłady i odczyty były szkołą retoryki, swobodnej a kunsztownej polszczyzny, elegancji i szlachetnego aktorstwa.

Gdy wiemy tyle o Z. Klemensiewiczu, fakty z jego biografii nabierają specjalnego sensu. Nie było to życie obfitujące w wielkie - poza dziejowymi - wydarzenia, w barwne podróże - poza dokształcającymi i służbowymi, w zaszczyty i godności poza oczywistymi. A przy tym nie gładkie, nie spokojne, bezpośrednio splątane i determinowane przez historię. Ingerencje te były zawsze bolesne i niełaskawe dla losów profesora.

Najistotniejszymi cezurami tej biografii są dwie wojny światowe. Pierwsza zamyka młodość, która upłynęła między miastami galicyjskimi: Tarnowem, gdzie się urodził, Nowym Sączem, Rzeszowem i Krakowem. Przyczyną tych migracji był status społeczny typowej rodziny inteligenckiej, kolejne nominacje i awanse w karierze prawniczej ojca. 
Na pobyt w Nowym Sączu przypada w 1909 r. matura Zenona. Po niej studia polonistyczne na Uniwersytecie Jagiellońskim u profesorów Jana Łosia, Ignacego Chrzanowskiego, Mikołaja Mazanowskiego, Jana Rozwadowskiego. W chwili wybuchu I wojny światowej wybijający się student jest już absolwentem polonistyki ze specjalnością literacką (temat pracy magisterskiej: Józef Korzeniowski jako dramaturg), odbywającym praktykę w obranym z pełnym przekonaniem zawodzie nauczyciela.

Nie podejmuje go - zostaje powołany do wojska austriackiego, w którym służy przez całą wojnę, a po jej zakończeniu - jeszcze rok w polskim wojsku. Możemy sobie wyobrazić, jak ciężką próbą dla jedynaka i humanisty było tych pięć lat w mundurze. Sprawdził się jako żołnierz, kolega, opiekun ludzi (był oficerem sanitarnym) i koni, zyskując w każdej roli najwyższe pochwały.

Do przeżyć całego pokolenia dołącza się rodzinne, które wywołuje jego własną nerwicę serca - w roku 1917 umiera na gruźlicę ukochany ojciec.

W dwa lata później porucznik Klemensiewicz żegna się z kolegami (w archiwum rodzinnym zachował się fragment toastu na „pożegnalne wzniesienie kielicha”):

Nie taję dzisiaj, że wiele ciężkich chwil przeżyłem w tym szpitalu, wiele trosk i niepokoju. Ale sowito nagrodził mnie los, dając w zamian dwa najwyższe wedle mego mniemania dobra: miłość ludzką i spokój sumienia. Wiadomo dość powszechnie, że czyniłem najusilniejsze starania, by uzyskać zwolnienie i rozpocząć pracę w umiłowanym zawodzie. A jednak kiedy nadeszła chwila rozstania z tą instytucją, żal prawdziwy owładnął mną [...] (cyt. za: Klemensiewicz 1982: 29-30).

Rozpoczyna pełnienie „umiłowanego zawodu” - dwudziestoletnie nauczanie w Państwowym Gimnazjum im. Króla Jana III Sobieskiego w Krakowie łączone z pracą społeczną w Związku Nauczycielstwa Szkół Wyższych, wykładami w Studium Pedagogicznym UJ, Instytucie Pedagogicznym w Katowicach, pracą naukową. Pojawiają się pierwsze publikacje, w 1925 r. uzyskuje stopień doktora na podstawie rozprawy Orzecznik przy formie osobowej słowa „być”, napisanej pod opieką J. Łosia.

Pół roku 1927 spędza na stypendialnych podróżach po zachodniej Europie, w Austrii, Szwajcarii, Francji, Belgii, Niemczech, gdzie zapoznaje się z metodami nauczania języka, relacjonowanymi na łamach „Języka Polskiego".

$\mathrm{W}$ roku 1930 uzyskuje habilitację z językoznawstwa (na podstawie pracy: $L i$ czebnik główny w polszczyźnie literackiej. Historia formy i składni (Klemensiewicz 1930a)), rozszerzoną w 1933 r. na pierwszą w Polsce habilitację z dydaktyki.

W tym okresie dane biograficzne wymieniają się na bibliograficzne - to, co się dzieje w życiu młodego uczonego, nosi tytuły kolejnych prac, powierzanych zadań i godności.

Ukazują się artykuły poprzedzające powstanie Składni opisowej wspótczesnej polszczyzny kulturalnej (Klemensiewicz 1937), kolejne podręczniki szkolne, trwa energiczna działalność poprawnościowa, od 1922 r. w ramach Zarządu Głównego Towarzystwa Miłośników Języka Polskiego, we współpracy z Łosiem i Nitschem. 
W 1930 r. redaguje Klemensiewicz Prawidła poprawnej wymowy polskiej (Klemensiewicz 193ob), następnie zostaje generalnym referentem Komitetu Ortograficznego.

W czerwcu 1939 r. przychodzi nominacja na profesora Uniwersytetu Jagiellońskiego. I tak jak przed półwieczem wojna przekreśla pomyślne perspektywy. Kapitan rezerwy zostaje zmobilizowany z rozkazem udania się do Lwowa - jednak w zawierusze pierwszych dni wojny nie dane mu jest połączyć się ze swoim batalionem. Wraca do Krakowa już pod okupacją, czeka go tu tragiczna relacja o uwięzieniu profesorów UJ.

Przypadek oszczędził mu obozowego losu kolegów, tym większe nałożył na siebie zobowiązania pełnione w codzienności okupacyjnej. Oficjalnie jest wykładowcą szkoły handlowej, równolegle naucza konspiracyjnie, wchodzi w skład komisji do zmiany programu nauczania obmyślanego na okres już powojenny przez tajny Departament Oświaty i Kultury. Nie porzuca badań, wprost przeciwnie, intensyfikuje pracę naukową - nad morfologią, semantyką, historią języka.

Praca nauczycielska prof. Klemensiewicza w okresie okupacji to osobny rozdział jego działalności pedagogicznej. Jeśli zawsze i świadomie czynił z każdej lekcji wydarzenie, to w warunkach konspiracji było to wydarzenie polityczne i patriotyczne, było to wydarzenie estetyczne. W najgorętszych słowach wspominają te kontakty uczestnicy zajęć Profesora (w książce Alma Mater w podziemiu (Siudut 1964; Heise 1964)).

Przemycał treści niedozwolone także w codziennej pracy z uczniami szkół handlowych. Zachował się w rękopisie z 1942 r. cykl wykładów przeznaczonych dla nauczycieli korespondencji handlowej. Pod powierzchnią wskazówek metodycznych płynie tam nurt drugi - nie opuszcza wykładowca żadnej okazji, żeby uświadomić słuchaczom obowiązki wobec ojczystego języka, aby potępić jego zniekształcanie, zaniedbanie. Są to lekcje walki o język, które uczyły dumy z jego historii i urody, szacunku i miłości, wszystkiego tego, co powinien czuć dla swojej mowy dobry Polak. Dobry Polak - to postawa, którą z całą powagą i naturalnością, przyjmując wszystkie jej życiowe konsekwencje, reprezentował zawsze Klemensiewicz.

Taka też jest geneza projektu Historii języka polskiego (Klemensiewicz 1961, 1965, 1972). W udostępnionej nam przez I. Bajerową dedykacji pierwszego tomu książki zwierza się: „I w grudniu 1939 powziąłem postanowienie opracowania historii języka ojczystego. Miał to być duchowy udział w walce narodowej, miało to być źródło wsparcia i sens życia” (Bajerowa 2011: 128).

Przeżywał tę wojnę bardzo osobiście jako wielki dramat: „I minął znowu rok, trzeci rok. Los nasz coraz cięższy. Na triumf myśli Boskiej nad złem i zbrodnią daremnie się czeka. Rzeczywistość smaga nas okrutnie, złudzenia pierzchają. Znikąd jednego jasnego promienia. Bardzo trudno żyć” (ibid.).

Wyczekiwany koniec wojny przywraca trwały już związek z Uniwersytetem Jagiellońskim. Profesor zostaje organizatorem i kierownikiem Katedry Języka Polskiego (od funkcji tej zostaje wkrótce odsunięty), dziekanem Wydziału Humanistycz- 
nego. Wyzwala się nowa energia naukowca i społecznika. Lata 1945-1969 przynoszą 400 publikacji. Pola działania mnożą się i rozszerzają. W roku 1946 zostaje członkiem korespondentem PAU, w 1961 członkiem rzeczywistym PAN.

W tymże roku dotyka go trudne dla jego ambicji i uczuciowości wydarzenie. Zgodnie $\mathrm{z}$ prawem, ale niezgodnie $\mathrm{z}$ dobrymi obyczajami, zostaje $\mathrm{w}$ dniu 70 urodzin odesłany na emeryturę zarówno uczelnianą, jak i PAN-owską (z Zakładu Językoznawstwa).

Po półwieczu niezwykle intensywnej, owocnej pracy w obu instytucjach odchodzi niepożegnany w żaden sposób, bez możliwości kontaktu choćby w ułamkowym wymiarze z młodzieżą, którą kochał z wzajemnością, on, niezastąpiony wykładowca i dydaktyk. Jego podręczniki zostają wycofane z nauczania. Pozbyto się człowieka i uczonego wielkiego formatu.

Był to okres w życiu Profesora bolesny. Zachował i wtedy niezwykłą klasę, bez słowa komentarza, zdradzającego, jak został zraniony.

Nie zapomnę, jak wychodząc z naszej Pracowni przy ul. Straszewskiego 27, stanął w drzwiach, niezwykle elegancki, blady, ze ściągniętą twarzą i oznajmił nam krótko: „Idę się pożegnać. Ktoś to musi zrobić”.

Dowiedziałyśmy się potem, że ten gest i całą sytuację ciężko odchorował. Nie zaprzestał jednak intensywnej działalności na innych polach.

Pozostały mu funkcje we władzach PAN (m.in. został prezesem Krakowskiego Oddziału), był członkiem Rady Głównej przy Ministerstwie Oświaty i Szkolnictwa Wyższego, wiceprzewodniczącym Komitetu Językoznawstwa, wiceprezesem Związku Nauczycielstwa Polskiego.

Nie odmawiał nigdy prośbie o odczyt, uczestnictwo w konferencji. Pełnił pracochłonne funkcje członka rad naukowych, komitetów redakcyjnych czasopism i słowników. Przyjął przewodnictwo Rady Naukowej Ośrodka Badań Prasoznawczych w Krakowie.

2 kwietnia $1969 \mathrm{r}$. brał udział w jej warszawskich obradach. Miał to być pierwszy akt powrotu do zdrowia po jedynej w życiu długotrwałej chorobie.

Samolot, którym Profesor wracał, rozbił się o zbocze Policy, góry nad Zawoją. Okoliczności katastrofy właściwie do dziś nie zostały wyjaśnione.

Mieszkańcy tych okolic upamiętnili jego postać, nadając nazwisko Klemensiewicza szkole w Skawicy, a Polska Akademia Nauk ufundowała pamiątkową płytę na przełęczy Krowiarki.

\section{Literatura}

Bajerowa I., 1990, Kim był Zenon Klemensiewicz?, [w:] H. Bednarczyk, E. Głomb, K. Głombowa (red.), Zenon Klemensiewicz (1891-1969) (materiaty $z$ sesji naukowej $w 20$ rocznice śmierci uczonego), Tarnów, s. 11-20. 
Bajerowa I., 2011, Więcej niż dedykacja, [w:] R. Majkowska, E. Fiałek (red.), Zenon Klemensiewicz 1891-1969. Materiały z posiedzenia naukowego w dniu 19 czerwca 2009 r., Kraków, s. $127-129$.

Grybosiowa A., 2011, Terminowanie u mistrza, [w:] R. Majkowska, E. Fiałek (red.), Zenon Klemensiewicz 1891-1969. Materiały z posiedzenia naukowego $w$ dniu 19 czerwca $2009 \mathrm{r}$., Kraków, s. 140-141.

Heise E., 1964, Ocalmy od zapomnienia, [w:] M. i A. Zarębowie (red.), Alma Mater w podziemiu. Kartki z dziejów tajnego nauczania w Uniwersytecie Jagiellońskim 1941-1945. Praca zbiorowa, Kraków, s. 160.

KaєKowsKa A. (oprac.), 1973, Zapomniane konstrukcje składni średniopolskiej (170o-1780). Wybór przykładów, Wrocław.

KAєKowsKa A. (oprac.), 1974, Zapomniane konstrukcje składni nowopolskiej (1780-1822). Wybór przykładów, Wrocław.

KaŁKowsKa A. (oprac.), 1975, Zapomniane konstrukcje składni nowopolskiej (1822-1863). Wybór przykładów, Wrocław.

KaŁKowsKa A. (oprac.), 1977, Zapomniane konstrukcje składni nowopolskiej (1863-1918). Wybór przykładów, Wrocław.

Ka€kowska A., Pisarkowa K., Twardzikowa J. (oprac.), 1972, Zapomniane konstrukcje składni średniopolskiej (XVII wiek). Wybór przykładów, Wrocław.

KlemensiewiCz Z., 1930a, Liczebnik główny w polszczyźnie literackiej. Historia formy i składni, „Prace Filologiczne” XV, s. 1-130.

KlemensiewiCZ Z., 193ob, Prawidła poprawnej wymowy polskiej, Kraków.

KlemensiewiCZ Z., 1937, Składnia opisowa współczesnej polszczyzny kulturalnej, Kraków.

Klemensiewicz Z., 1953, Zarys składni polskiej, Warszawa.

Klemensiewicz Z., 1958, Założenia i wytyczne działalności Pracowni Polskiej Składni Historycznej, „Zeszyty Naukowe UJ”, „Filologia” nr 4, „Prace Językoznawcze” nr 3 (nadb.).

Klemensiewicz Z., 1961, Historia języka polskiego, cz. 1: Doba staropolska, Warszawa.

Klemensiewicz Z., 1965, Historia języka polskiego, cz. 2: Doba średniopolska, Warszawa.

Klemensiewicz Z., 1972, Historia języka polskiego, cz. 3: Doba nowopolska, Warszawa.

Klemensiewicz Z., 1982, Składnia, stylistyka, pedagogika językowa. Wybór prac, red. A. Kałkowska, Warszawa.

KlemensiewiCz Z., Lehr-SpŁawiński T., UrbańCZyk S., 1955, Gramatyka historyczna języka polskiego, Warszawa.

Klemensiewicz Z., Pisarkowa K., Konieczna-Twardzikowa J. (oprac.), 1966, Zapomniane konstrukcje składni staropolskiej. Wybór przykładów, Wrocław.

Pisarkowa K., 1990, Wspominanie Profesora Klemensiewicza, [w:] H. Bednarczyk, E. Głomb, K. Głombowa (red.), Zenon Klemensiewicz (1891-1969) (materiały z sesji naukowej w 20 rocznicęśmierci uczonego), Tarnów, s. 21-29.

Pisarkowa K., 2011, Zenon Klemensiewicz dla mego pokolenia, [w: ] R. Majkowska, E. Fiałek (red.), Zenon Klemensiewicz 1891-1969. Materiały z posiedzenia naukowego $w$ dniu 19 czerwca 2009 r., Kraków, s. 133-137.

Siudut Z., 1964, Nasze uniwersytety, [w:] M. i A. Zarębowie (red.), Alma Mater w podziemiu. Kartki $z$ dziejów tajnego nauczania w Uniwersytecie Jagiellońskim 1941-1945. Praca zbiorowa, Kraków, s. 130-132. 


\section{Zenon Klemensiewicz in His Time. From the Memories of a Pupil \\ Summary}

The author, a witness of the last twenty years of Professor Zenon Klemensiewicz's life and activity, reminds the importance of his person for the period he helped to shape. He went beyond linguistics, and became a separate value of cultural, moral, and national life. He symbolized the model of a Polish patriot and researcher, heir to humanistic traditions, a romanticist and positivist in one. The paper passes down the author's and the milieu's memories of the rich and complex personality of the master and the boss, his extraordinary didactic and rhetoric talent, it is an introduction to a personal and academic biography of a typical Polish intellectual determined by two world wars. 